\title{
NINTH CENTURY SYRIAC EXEGETE AND APOLOGIST: MOSHE BAR KEPHA'S COMMENTARY ON LUKE
}

\author{
ABDUL-MASSIH SAADI \\ BAYLOR UNIVERSITY
}

\begin{abstract}
S
Moshe Bar Kepha, as a churchman, exegete and apologist, lived in the time and place of the most troubled center of the Abbasid Empire, witnessing the consequences of its policies upon the Christian communities. The most daring policy was the Islamization policy of Caliph al-Mutawakekil (d. 861), under which Christianity was not merely assailed as a false faith, but also as a social evil. In addition to paying Jizyah, this caliph further humiliated the Christians by imposing on them harsher rules which came to be known as "Umar Conditions."

It was in the context of enduring the Islamization policy and in the context of open and receptive relationships among Christians of different traditions that Moshe Bar Kepha ministered, taught, and wrote his Commentary on the Gospel of Luke. In fact, he produced a masterpiece of an inclusive (ecumenical) theological approach, and with apologetic tendency responding to Muslims.
\end{abstract}


Through examples from his Commentary, I will illuminate Moshe Bar Kepha's position on various theological topics. He presented them in a harmonious way, stressing the essential unity among all Christians. At the same time, by means of instructing his Christian community, Moshe Bar Kepha responded to Muslims' challenge to the Christian faith.

\section{INTRODUCTION}

In the second half of the $9^{\text {th }}$ century, the Syriac Christian communities were shaken by the radical shift of the social and religious policies of the Abbasid Empire brought by the $10^{\text {th }}$ Caliph, al-Mutawakkil (847-861), and the continuation of these policies through his successors. ${ }^{1}$ As these new policies were implemented, Islamic authorities severely oppressed $\mathrm{Mu}^{\mathrm{c}}$ tazilites, Christians, and other religious groups. ${ }^{2}$ Along with many Christians, Moshe Bar Kepha suffered under the new policies, which severely harassed the Christian communities: economically, socially, physically, psychologically, and religiously. ${ }^{3}$

1 Moshe Bar Kepha was contemporary to six of al-Mutawakkil's successors: al-Muntasir (861-862), al-Mustacin (862-866), al-Muctaz (866869), al-Muhtadi (869-870), al-Muctamid (870-892), al-Muctadid (892-902), and al-Muktafi (902-908).

2 A. Abuna, The History of the Eastern Syriac Church [تاريخ الكنيسة السريانية الشرقية] Vol. 2 (Beirut: Dar al-Mashriq, 1993), 173-8.

${ }^{3}$ Mari and Saliba, the thirteenth century East Syriac historians, bitterly complained about al-Mutawakkil's polices, saying: "He had subjugated the scholars and the writers of his time and diminished their honor, and made science and its seekers his enemy. Moreover, he killed many authors and confiscated their properties and destroyed their homes. Thus, the people of Dhimmi [Christians] suffered a great deal of afflictions, harms, and humiliation by forcing them to change their clothes, and through destruction of their churches and cemeteries, leveling it with the earth... Furthermore, in all places, he ordered the humiliation of Nasareh [Christians], and to make them wear blue robes." See H. Gismondi, ed., Maris Amri et Slibae, De Patriachis Nestorianorum Commentaria (Rome: Excudebat de Luigi, 1899) 79. B. Holmberg argues for an earlier date of this work by a different author. The new author is ${ }^{\mathrm{c}} \mathrm{Amr}$ Ibn Matta, who is 
The pessimistic outlook of Christians at this time was clearly reflected by the contemporary East Syriac apologist, Yuhanna b. Masawayeh. Yuhanna cried, "Nowadays, Christ himself would become Muslim under the pressure of al-Mutawakkil." ${ }^{\text {4 }}$

Al-Mutawakkil's rules, which he ascribed to 'Umar (the second Rashidite Caliph, d. 644), and which became known as the "Covenant of "Umar," or the "Conditions of 'Umar," greatly restricted the freedom of Christians. ${ }^{5}$ Among other restrictions, the Conditions forbade Christians from criticizing Islam on pain of death. ${ }^{6}$ Furthermore, al-Mutawakkil imposed psychological pressure on both lay and learned Christians by recruiting Muslim writers to humiliate the Christians, especially in the eyes of the Muslim populace, and to challenge Christian

responsible for the first seven-chapter Work in the early $11^{\text {th }}$ century; the other five-chapter work authored by Saliba Ibn Yuhanna in the $14^{\text {th }}$ century; Mari Ibn Sulayman is just a "continuer" author, who added more material related to the $14^{\text {th }}$ century. See B. Holmberg, "A Reconsideration of the Kitāb al-Magdal,” Parole de l'Orient 18 (1993): 255-273, esp. 268.

4 Nizanr Riza, ed., Iwan al-Anbaa fi Tabaqat al-Atibaa [عيون الأنباء في طبقات الأطباء (Beirut: Dar Maktabat al-Hayat, 1965) 250.

${ }^{5} \mathrm{~J}$. Fiey details the "Umar Conditions" imposed by al-Mutawakkil, and discusses their humiliating impact on the Christians. See J. Fiey, Abwal AlNasara [احوال النصارى في خلافة بني عباس] Trans. Husni Zinah (Beirut: Oriental Library, 1990), 141-2; Chrétiens Syriaques Sous Les Abbasides surtout à Bagdad (749-1258), CSCO 420, Subs. 59 (Louvain: Secrétariat du CorpusSCO, 1980) 87-90; see also, A. S. Tritton, The Caliphs and their Non-Muslim Subjects, a Critical Study of the Covenant of cUmar (London: Oxford University Press, 1930).

${ }^{6}$ The Covenant of 'Umar states: "If any of you says of the Prophet, of God's book or his religion what is unfitting, he is debarred from the protection of God, the Commander of the Faithful, and all Muslims; the security on which was given is annulled." See A. Tritton, The Caliphs and their Non-Muslim Subjects, 12. 
teachings. ${ }^{7}$ As a result of this policy, many priests, bishops and theologians were imprisoned and many suffered silently. ${ }^{8}$

In such strained circumstances, the Christian communities, with no capacity to respond to these policies, endured their fate, but they dealt internally with their religious differences in harmonious ways. It would seem that this more cordial relationship between Christian communities was partially in reaction to the aggressive Islamization policy of al-Mutawakkil. The Muslims always viewed the differences among Christians as an obvious sign of the incredulity of Christian faith, as they invoked their scripture saying, "We caused among them [Christians] animosity and hatred until the Day of Resurrection." Muslim debaters often highlighted this topic in their refutation of the Christian faith. ${ }^{10}$ They also frequently

${ }^{7}$ Al-Jahiz explains that his Letters against Christians were in response to al-Mutawakkil's request. See A. Harun, ed., Rasail al-Jahiz. [رسائل الجاحظ] Vol. 3, (Cairo: al-Hangi, 1979), 303-351, esp. 303. Likewise, ' Ali Ibn Rabban alTabari, the East Syriac physician, converted to Islam and responded to alMutawakkil's command, wrote a treatise against Christians entitled, al-Radd "ala al-Nasara or "Refutation of the Christians;" see A. Nuweihed, ed., Kitab al-din wal-dawla [كتاب الدين والدولة], (Beirut: Dar al-Afaq al-Jadida, 1979), 34-36; A. Mingana, trans., The Book of Religion and Empire (Manchester, LongmansGreen, 1922), 2-5.

8 S. Moffett, A History of Christianity in Asia, Vol. 1 (New York: HarperSanFrancisco, 1992) 357-9.

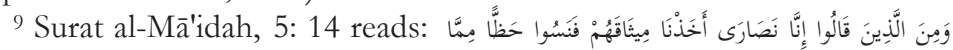

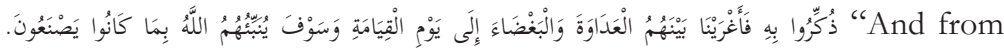
those who say, 'We are Christians' We took their covenant; but they forgot a portion of that of which they were reminded. So we caused among them animosity and hatred until the Day of Resurrection. And Allah is going to inform them about what they used to do."

${ }^{10}$ For example, the contemporary al-Jahiz (d. 869) declared: "Even if one were to exert every effort, and summon all his intellectual resources for understanding their teaching concerning Christ, he would still fail to comprehend the nature of Christianity, especially its doctrine of the Divinity. How can you understand that, for if you asked about Christ to two Nestorians, sons of the same father and mother, the answer of the first one would contradict the answer of his brother. This holds true also of the Melchites and Jacobites." See Al-Jahiz, 333-334. 
criticized Christian doctrines, including the divinity of Jesus, the Trinity, the Incarnation, the integrity of the Bible, free will, and the concept of Paradise.

By way of instructing his community, Moshe Bar Kepha writes and elaborates on these topics, focusing on the divinity of Christ in his Commentary on the Gospel of Luke, ${ }^{11}$ but only to conclude that Christians are in agreement with all points that define the Christian faith. At the same time, he opportunely uses these same topics to clarify the differences between believers and Muslims. But unlike the Muslims, who aim to undermine the Christian faith and gain converts, the restricted Moshe Bar Kepha aims to protect his Christian community by way of instructing them with biblical responses to the Muslims' objections.

It was in the context of enduring the Islamization policy of al-Mutawakkil and in the context of open and receptive relationships among Christians of different traditions that Moshe Bar Kepha, the Syriac Orthodox bishop, ministered to his community and wrote his Commentary on the Gospel of Luke. His Commentary models an ecumenical and theological approach, especially the Christology, along with apologetic concern with Islam. ${ }^{12}$

\section{Writing STRATEgY AND LiterARY GENRE}

Moshe Bar Kepha's writing strategy is characterized by his even-handed treatment of the theology of various Syriac traditions, namely, the East Syriac (Nestorians), the Syriac Melkites (Chalcedonians), the Syriac Maronites, and the West

11 A. Saadi, "Moshe Bar Kepha's Commentary on Luke: A Ninth Century Apology." Ph.D. dissertation, Lutheran School of Theology at Chicago, 1999. The Commentary survived in a single manuscript, now located in Mardin, at the Church of the Holy Martyrs, under number 102; an edition and translation by the present author is in press.

${ }^{12} \mathrm{~J}$. Reller, in his introduction, briefly referred to Moshe Bar Kepha's apologetic tendency responding to Muslims; however, Reller did not elaborate on the topic, nor did he give examples. See J. Reller, Mose bar Kepha und seine Paulinenauslegung (Wiesbaden: Otto Harrassowitz, 1994). 
Syriac (Jacobites). Throughout his Commentary, Moshe Bar Kepha avoids the controversial watchwords of Christology, such as one or two Nature (s), one or two Hypostasis (-es), one or two Will(s), etc. In fact, on many topics, Moshe Bar Kepha resorts to the early Syriac theological theme, namely, "the divine mystery," propagated by St. Ephrem, ${ }^{13}$ and the "incomprehensibility of the Word of God" in order to foster harmony among diverse Christians. ${ }^{14}$ Under the theme of "the divine mystery," he discusses the various and diverse views among Christian traditions, even within the same tradition, but only to conclude that these differences point to the common belief in the Godhead of Christ, the Word of God. ${ }^{15}$ By following this strategy, Moshe Bar Kepha aims at presenting an easy, accessible, acceptable and uniform Christian teaching for the instruction of the Christian communities in the face of Islamization policies. Additionally, Moshe Bar Kepha employs the term "heretics" ostensibly to refer to ancient, non-

${ }^{13}$ S. Brock and G. Kiraz, Ephrem the Syrian: Select Poems (Provo: Brigham Young University Press, 2006), 16-17; D. Taylor, "The Syriac Tradition," The First Christian Theologians: An Introduction to Theology in the Early Church, edited by G. R. Evans, 206ff. (Malden/ Oxford/ Victoria: Blackwell, 2004).

${ }^{14} \mathrm{D}$. Bundy argues that the common principles of early Syriac authors were the Scriptures as a source of knowing the divine revelation, the perfect life style, the free will, and the inability of language to express the divine truth. See D. Bundy, "Criteria for Being 'in communione' in the Early Syriac Church," Augustinianum 25:3 (1985): 597-608.

${ }^{15}$ Moshe Bar Kepha followed a trend of Syriac literature that focuses on biblical and theological themes that instruct all Christian communities, avoiding details of Christological doctrines. In a more direct way, the $11^{\text {th }}$ $12^{\text {th }}$ century West Syriac apologist, Arfadi, after naming all diverse Christian denominations, stated that "all agree in confessing both the divinity and humanity of Christ our Lord." See G. Troupeau, "Le livre de l'unanimité de la foi de ' Alī ibn Dāwud al-Arfādī," Melto 5:2 (1969): 210-211. Likewise, Bar Hebraeus (1286), confirmed that the theological differences among Christians are insubstantial. He concluded, saying: "Thus I discovered, that all Christian peoples, notwithstanding their differences, are in concord with each other." See P. Bedjan, ed., Liber columbae seu Directorium monachorum Gregorii Barhebraei (Paris / Leipzig: Otto Harrassowitz, 1898) 577-8; English trans., A. Wensinck, Bar Hebraeus's Book of the Dove together with some Chapters from his Ethicon (Leiden: E.J. Brill, 1919) 60. 
canonical Christian teaching, which had mostly ceased to exist, yet surreptitiously he uses it to refer to Muslims. Like many Christian apologists, he did not use the term "Islam" or "Muslims" in his writings. ${ }^{16}$ In fact, Islam was clearly viewed as "heresy" by Christian communities over a century before the time of Moshe Bar Kepha. John of Damascus (d. 753) dedicated a chapter of his work De Haeresibus to "the heresy of the Ishmaelites (Muslims)". ${ }^{17}$ In effect, by the ninth century, the Christian apologists had perceived Muslims' beliefs as akin to that of the Jews, ${ }^{18}$ to some Judeo-Christian heresies, or to Marcionites, Manicheans, Arians, ${ }^{19}$ and some ancient pagans. ${ }^{20}$ By employing this strategy, Moshe Bar Kepha has two goals in mind: First, to respond to the Muslims' challenges without

16 Most of the Christian apologists referred to Muslims in different terms rather than naming them explicitly. See S. Griffith, "Chapter Ten of the Scholion: Theodore Bar Kônî’s Apology for Christianity,” Orientalia Christiana Periodica 47 (1981): 168.

17 According to John of Damascus, Mameth formed a heresy of his own after supposedly encountered an Arian monk. See D. Sahas, John of Damascus on Islam: The "Heresy of the Ishmaelites" (Leiden, The Netherlands: Brill, 1972), Appendix I, De Haeresibus, 133.

18 The Syriac writers considered Muslims as "Jews," or "new Jews." See A. Saadi, "The Letter of John of Sedreh: A New Perspective on Nascent Islam," Journal of the Assyrian Academic Society, 11.1 (1997): 70; Theodore Bar Kōni (d. 792), describes Muslims as "believing as the Jews," see Addai Scher, ed., Theodorus Bar Kōni Liber Scholiorum, CSCO Syr. II. 66 (Paris: Typographeo Reipublicae, 1912), 235; likewise, Patriarch Timothy (d. 823) sees them as "the new Jews among us;" S. Griffith, "Disputes with Muslims in Syriac Christian Texts: From Patriarch John (d. 648) to Bar Hebraeus (d. 1286)," Religionsgespräche in Mittelalter, edited by Niewöhner, F. (Wiesbaden: Otto Harrassowitz, 1992), 264; . J. B. Chabot, ed., Chronique de Michel le Syrien, Vol. 4 (Paris: Culture et Civilisation, 1963) 405; I. Aphram Barsoum and J. B. Chabot, eds., Chronicon anonymum ad annum Christi 819 pertinens, CSCO 81, Syr. 36 (Paris: Secrétariat du CorpusSCO, 1920), 227-8

${ }^{19}$ Daniel J. Sahas, John of Damascus on Islam, 26, 133.

${ }^{20}$ S. Griffith, "Free Will in Christian Kalam: Moshe Bar Kepha Against the Teachings of the Muslims," Le Muséon 100: 1-2 (1987): 159. Moreover, Griffith stresses that Moshe Bar Kepha's treatise suggests that he must have been well versed in the traditional points of controversy between Christians and Muslims. 
risking any dangerous consequences; second, to instruct and assure his faithful community of its beliefs and strengthen its own sense of religious credibility.

Moshe Bar Kepha writes his Commentary in dialectical style ( $\kappa_{x i n x}$ ), which is part of the literary tradition of formal discourse in the Syriac schools. ${ }^{21}$ He often starts his explanations by saying: "they say," "others ask," "let us ask," and "we answer." Moshe Bar Kepha converses with his readers by reviewing others' viewpoints on a certain verse, then interpreting the verse himself. Such a literary genre enables Moshe Bar Kepha to be inclusive in his arguments, which are ultimately apologetic in nature. ${ }^{22}$

\section{Moshe BAR KePHA's Apologetic Topics}

Moshe Bar Kepha's apologetic theme runs throughout his Commentary verse after verse and episode after episode, explaining, expounding and declaring Christ as Lord and God, one of the Holy Trinity, and equal with his Father. ${ }^{23}$ His apologetic intention is clearly directed to Muslims' objections when he addresses it to "heretics," or when he deals with a distinct topic such as Paradise. As his contemporary, Nonnus of Nisibis, who wrote Commentary on the Gospel of John, ${ }^{24}$ spared no place to make an apology for the divinity of Christ. ${ }^{25}$ At the

${ }^{21}$ S. Griffith, "Chapter Ten of the Scholion: Theodore Bar Kônî’s Apology for Christianity," Orientalia Christiana Periodica 47 (1981): 170.

$22 \mathrm{M}$. Cook argues that such conversational style may be the ancestor of the distinctive rhetorical form of the Arabic 'ilm al-kalam. Cf. Michael Cook, "The Origins of Kalām," Bulletin of the School of Oriental and African Studies, 43:1 (1980): 32-43.

${ }^{23}$ Griffith explains that the divinity of Christ and the incarnation became a hot topic for all Christian apologists since the Quran manifestly denies them. See S. Griffith, "Disputes with Muslims in Syriac Christian Texts: From Patriarch John (d. 648) to Bar Hebraeus (d. 1286),” 245.

${ }^{24}$ Robert W. Thomson, Nonnus of Nisibis, Commentary on the Gospel of Saint John (Atlanta: Society of Biblical Literature, 2014).

25 Van Roey observed the apologetic intention of Nonnus of Nisibis in responding to Muslims in the way he explained the divinity of Christ; see 
same time, Moshe Bar Kepha elaborates on all kinds of differences among Christians' interpretations, as far as the contents of the Gospel of Luke allows, but only concluding that Christians are in agreement with all points that define the Christian faith.

\section{Christological Topics}

\section{The Word of God is God}

Invoking the Qur'anic reference to Jesus as "the word of God" and as a "Spirit from Him," 26 Moshe Bar Kepha comments on Luke 1:2, which reads: "Those who were eyewitnesses and ministers of the Word." Moshe Bar Kepha explains that the disciples experienced and ministered to the Word of God, not merely to a man. Moshe Bar Kepha writes: "[the Gospel] says that the apostles saw and ministered to the Word of God, not merely a human being as the wicked say." 27 Moshe Bar Kepha continually reaffirms that "truly the Word, God, was seen in flesh."28 In these comments, Moshe Bar Kepha clearly underscores the central Christian theme of the divinity of Jesus. As many Christian apologists before him, ${ }^{29}$ he repeatedly

A. Van Roey, A. Van Roey, Nonnus de Nisibe.Ttraité apologétique, Bibliothèque du Muséon 21 (Louvain: Bureaux du Muséon, 1948) 29.

26 Cf. Sura 4 (Women):171, which reads: إنما إِنَّمَا الْمَسِيحُ عِيسَى ابْنُ مَرَيَمَ رَسُولُ اللَّهِ

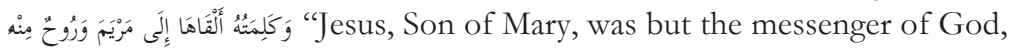
and His Word — the Word which He imparted to Mary—and a Spirit from Him."

27 All Moshe Bar Kepha's quotations are taken from his surviving Syriac manuscript 102 in Mardin Syrian Orthodox Manuscripts Library; while an edition and translation are in press, the reader may confer with my

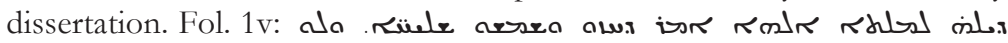

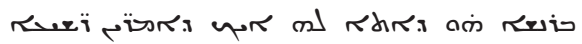

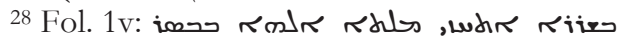

${ }^{29}$ The writing of the Monk of Bêt Halê, in the eighth century, reflects the Christians' conviction that these terms occurring in the Quran, "Word of God," and "Spirit from God," imply Christ's divinity. See S. Griffith, "Disputing with Islam in Syriac: The Case of the Monk of Bêt Halê and a Muslim Emir," Hugoye: Journal of Syriac Studies 3:1 (2000): 9. 
makes use of the Quranic term, "the Word from Him [God]," 30 as a title for Christ, leveraging his argument from Muslim scripture (Qur'ān), ${ }^{31}$ although the Muslims do not consider the Qur'ān's description of Jesus to imply his divinity. ${ }^{32}$

\section{Paradise}

Concerning the controversial topic of Paradise, Moshe Bar Kepha contrasts the spiritual concept of the Christians' Paradise with the earthly concept of the Muslims' Paradise. ${ }^{33}$ For example, in Luke 1:17, which reads, "and to prepare for the Lord a perfect people," Moshe Bar Kepha identifies perfect people with Christians because they are concerned with and hope for heavenly reward, "and not hoping for a land that flows with milk and honey." 34 Although neither the verse nor

30 The Qur'an has Jesus as kalima minhu كلمة منه "Word from Him” (Q

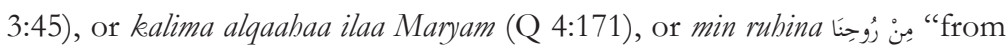
Our Spirit," but not as kalimat allah كلمة الله "the Word of God," as it is read in the Gospel.

31 John of Damascus, in a context of encounter with a Saracene (Muslim), says that Christ is "Word of God," just as it reads in Christian Scripture, "Christ is called Spirit and Word of God;" likewise in your (Islamic) Scripture is called, "The Spirit and the Word of God." See D. Sahas, John of Damascus on Islam, 149.

32 cAdb al-Jabbar (d. 1025), a Muslim apologist, argues that "if you asked the disputants and debaters among them [Christians] about their statement on Christ, they would say, "Our statement is that he is the Spirit of God and His Word, just like the statement of Muslims. We say, 'God is One."' See "Abd al-Jabbar, The Critique of Christians: A Parallel English-Arabic Text, S. Samir, ed., G. Reynolds, trans. (Provo: Brigham Young University Press, 2010), 2-3.

${ }^{33}$ Cf. Quranic references to Paradise, Sura 47 (Muhammad): 15, Sura 2 (the Cow) 25; Sura 56 (the Invitable) 15-26.

34 Moshe Bar Kepha was drawing on Ephrem's explanation of this verse; while Ephrem identifies the perfect people as people who fear the Lord (i.e., the Christians), and who do not worship idols, Moshe Bar Kepha identifies the perfect people as the people who seek the Kingdom of Heaven (i.e., the Christians), and not the people who seek a land that flows

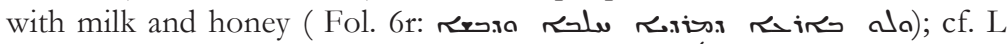
Leloir, ed. and trans., Saint Ephrem: Commentaire de l'Évangile Concordant, Texte 
the context refers directly to Paradise, Moshe Bar Kepha uses this verse to address this topic and covertly criticize Islamic doctrine. ${ }^{35}$

\section{The Doctrine of Christ and God are Identical}

Commenting on Luke 1:16, the annunciation by the angel Gabriel to Zechariah that his son "will turn the Israelites to the Lord their God," Bar Kepha identifies God with Christ. Moshe Bar Kepha responds to the objections of "the heretics," an implicit reference to Muslims, who claim that according to the angel, John will turn the people to their God and not to Christ. Moshe Bar Kepha, on the other hand, argues that the word Jesus Christ did not appear here because it was hidden from the angel, and it was kept secret to be announced at the proper time. ${ }^{36}$ While Moshe Bar Kepha's opponents separate God and Christ, he asserts that "the Lord their God," refers only to Jesus Christ.

Again, in Luke 2:11, which reads, "Behold a Savior is born for you, who is the Lord, the Messiah," Moshe Bar Kepha demonstrates the identity of Jesus Christ as the Lord God from the angel's declaration. Then he elaborates, saying that Christ is with the Father in eternity, where there is no time or space; this human birth, however, is for us and for our salvation, and

Syriaque (Manuscrit Chester Beatty 709) Chester Beatty Monographs 8 [Syriac and Latin] (Dublin: Hodges Figgis, 1963) 20; Saint Ephrem's Commentary on Tatian's Diatessaron: An English Translation of Chester Beatty Syriac Ms 709 with Introduction and Notes, Journal of Semitic Studies Supplements 2, Carmel McCarthy, (Oxford: Oxford University Press, 1993) 52.

35 Nonnus of Nisibis (d. 870), the West Syriac apologist, like Moshe Bar Kepha, caricatures the Muslims' description of Paradise, but without mentioning their name. He writes: "Rivers of fattening foods, along with time in bed, that do not satiate; a new creation of women whose birth is not from Adam and Eve, things known and acknowledged to incite carnal people." See A. Van Roey, Nonnus de Nisibe.Ttraité apologétique, Bibliothèque du Muséon 21 (Louvain: Bureaux du Muséon, 1948) 31*.

${ }^{36}$ Cf. Fol. 4v. 
not for the sake of Christ. ${ }^{37}$ Thus, Moshe Bar Kepha stresses the identification of Jesus Christ with the Lord God and rejects any reason to doubt Jesus' divinity or immortality, an issue frequently raised and rejected by Muslims.

\section{Jesus is Greater than John the Baptist}

In response to Muslim arguments that "Jesus is less than John the Baptist" on the account that Jesus was baptized by John the Baptist, ${ }^{38}$ Moshe Bar Kepha refers to John's own testimony when he confesses that Jesus is greater than he is. Moreover, Moshe Bar Kepha comments on Luke 1:76, which reads, concerning John, "And you will be called the prophet of the Most High for you will go before the face of the Lord." Moshe Bar Kepha then argues that if Christ is the Most High, and he has prophets like his Father, then he is the incarnated God. Moshe Bar Kepha hereby asserts not only the greatness of Jesus, but also his superiority as God over his messenger John. ${ }^{39}$

\section{Intentional Denial of Jesus' Divinity}

Commenting on Luke 2:35 concerning the prophecy of Simon the Elder: "And a sword will pierce through your soul, and the deeper thought of many would be revealed," Moshe Bar Kepha distinguishes between some who disbelieve in him because of their weakness and others because of their

${ }^{37}$ Although the theological topic of two births for Christ, eternal from the Father, and human birth from Mary is based on the Creed of Faith, it was also used as an apologetic response to Muslims for confirming Christ's divinity. See A. Saadi, "The Letter of John of Sadreh: A New Prospective on Nacent Islam," Karmo, 1.2 (1999): 49; Penn, Michael, "John and the Emir: A New Introduction, Edition and Translation,” Le Muséon 121:1-2 (2008): 86.

38 The Muslims were debating that the Christians should worship John the Baptist because, according to the Christians, Jesus was baptized by John. See D. Sahas, John of Damascus on Islam: The Heresy of the Ishmaelites (Leiden: Brill, 1972) Appendix, II, Disputatio Saraceni et Christiani, 155.

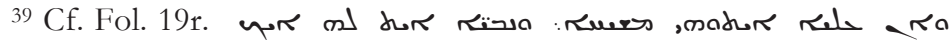

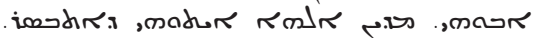


wickedness. While he clearly refers to the priests and the teachers of the Jews as non-believers because of their ill will, he surreptitiously refers to Muslims as "heretics." He says: "But these raise doubt in him because of their ill will, just as the priests and the teachers of those [Jews], and as the heretics of today." 40

\section{The Divinity of the Word of God from Birth}

Moshe Bar Kepha confirms the mainstream Christology among Christians that Mary conceived the Word of God, who came from heaven and not from earth, out of human seed. Therefore Christ is God, Moshe Bar Kepha confirms, not merely a man, as the heretics claim. ${ }^{41}$ Commenting on Luke 1:31, "For behold, you will receive conception and will bear a son," Moshe Bar Kepha elucidates this apologetic theme in two ways: First, displaying the common belief of all Christians that the Son who was born in Mary is "God the Word," in a mysterious way beyond human comprehension, despite their various interpretations. ${ }^{42}$ Second, in sharp contrast with Muslims who admit that Jesus was not of human seed but denounce Jesus' divinity. ${ }^{43}$

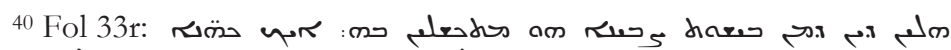

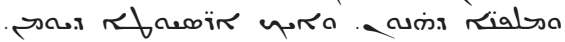

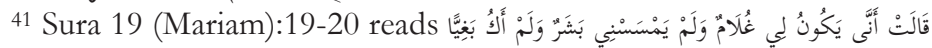
"She said, 'How
} can I have a boy while no man has touched me and I have not been unchaste? * He said, 'Thus [it will be]; your Lord says, 'It is easy for Me, and We will make him a sign to the people and a mercy from Us. And it is a matter [already] decreed."”

42 The various interpretations among Christians could be grouped as whether Mary should be called "Mother of God," or "Mother of Christ," but ultimately all confess the divinity of Christ.

${ }^{43}$ Anti-Christian polemics often resorted to Quranic verses that speak of Jesus just as human (Cf. Surah 3 ('Ali cImran): 59); Abu Ra `itha, a 9th century apologist, sees no contradiction of Jesus being fully human, but also fully divine. See G. Georg, ed., Die Schriften des Jacobiten Habîb ibn Hidma Abû Râ'ita CSCO 130, Arab. 14 (Louvain: L. Durbecq, 1951) 151. 
Moshe Bar Kepha questions his reader or listener: "how" and "whom" did Mary conceive, God or Man? And if they say he is a man, it is not true because the conception did not result (come) from Joseph nor from another man (just as also the Muslims admit). Therefore, Mary conceived God the Word. "How?" Moshe Bar Kepha asks. In response, Moshe Bar Kepha resorts to the traditional assumption of the Syrian theology of the incapability of the human language to express and the human mind to comprehend the "divine mystery." 44 He said that it all happened "in a way that we [humans] cannot express, comprehend, or explain his birth in flesh." 45

Commenting on Luke 1:35, which reads: "The Angel said, behold the Holy Spirit will come and the power of the Highest will descend upon you," Moshe Bar Kepha returns to the divine mystery concerning "how the conception occurred." $\mathrm{He}$ recalls many various interpretations given by Christians, but all signify the reality that the conception happened, just as it was announced by Gabriel. The conception happened even if the precise manner of "how" this conception took place is beyond the comprehension of humans and angels alike. He writes, "The Angel did not answer how Mary will conceive because this conception is beyond the knowledge of both Angels and human beings. For none can comprehend how the power of the Highest can be conceived in the Virgin except him [Christ] and his Father and the Holy Spirit." 46

44 Bundy, "Criteria for Being 'in communione' 608; Bundy, "Language and the Knowledge of God in Ephrem Syrus," Dialogue and Alliance 1.4 (1988) 60. see also B. Holmberg, "The Trinitarian Terminology of Israel of Kashkar (d. 872)," ARAM 3 (1991 [1993]): 58;

45 Fol. 6v (on 1:31):

אניה פדוili

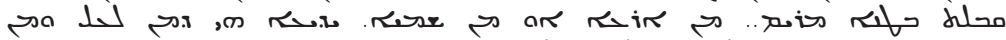

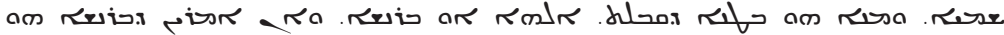

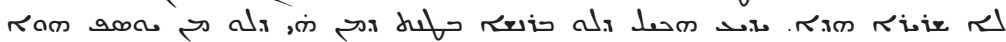
duli u

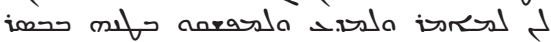

${ }^{46}$ Fol. 10r (on 1:35):

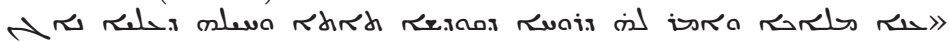


While "how" the Word of God was conceived is beyond comprehension, Moshe Bar Kepha explains that "the Angel revealed 'who' is the one that took flesh, and 'who' is the one who made him take flesh. For in the process of all creation, this order was followed: the Father commands the creation to be created, and the Son creates it, and the Holy Spirit guides and perfects it. Likewise here, the Father willed that the Son be incarnated for our salvation, and the Son enacted the incarnation, and the Holy Spirit made the Son take flesh because the Holy Spirit formed the body to which the Son is united hypostatically." ${ }^{47}$

Moshe Bar Kepha further elaborates on Luke 1:35 to respond to a hot topic of controversy between Christians and Muslims, namely, how can "the Word, God" be in the Virgin's womb, and at the same time in heaven ${ }^{48}$ As most Syriac apologists before him, Moshe Bar Kepha resorts to the traditional Christian response from the features of nature. ${ }^{49} \mathrm{He}$

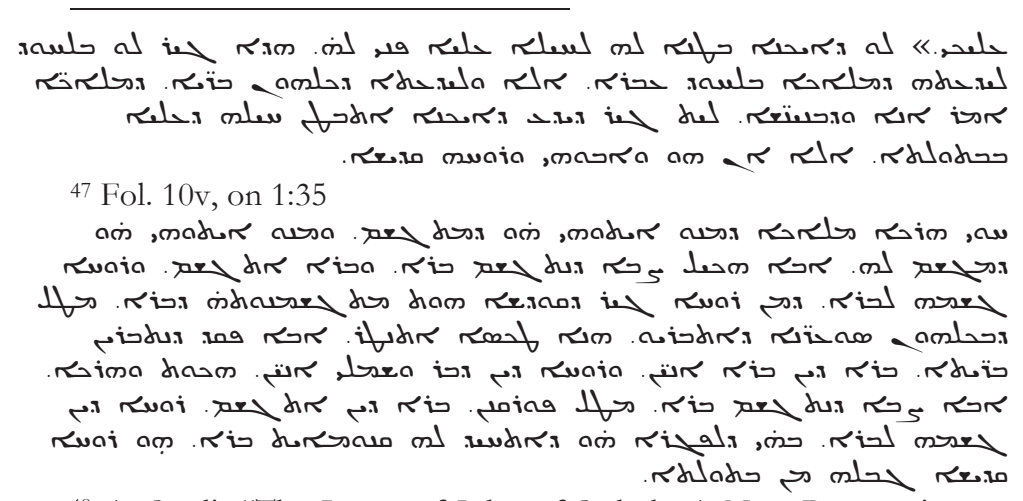

48 A. Saadi, "The Letter of John of Sadreh: A New Prospective on Nascent Islam," Karmo, 1.2 (1999): 49-50; Penn, Michael, "John and the Emir: A New Introduction, Edition and Translation," Le Muséon 121:1-2 (2008): 87.

${ }^{49}$ Theolodore Bar Koni, in his scholion, brought the same metaphor from nature as an apologetic response to Muslims concerning the divinity of Jesus and being One with the Father and the Holy Spirit. See A. Scher, ed., Theodorus Bar Köni, Liber Scholiorum, CSCO 69, Scriptores Syri 26 (Louvain: Secrétariat du CorpusSCO, 1960) 279. 
said, "They ask us how the Word, God, dwelled in the virgin?" We response: Just as he dwells in the creations while he is in (with) his Father, and just as the rays of the sun dwell in the world while they are in their sphere." 51

Arguing from within the East Syriac theology, Moshe Bar Kepha disagrees with Theodore of Mopsuestia, "the Nestorian," 52 who said, "the ones [the Son and the Holy Spirit] who descended towards Mary were not the hypostases of the Son and the Spirit but rather the operation of the Spirit and the capability of the Son." ${ }^{, 53}$ Rather than directly responding to Theodore, Moshe Bar Kepha chooses to respond to him from within East Syriac tradition (Nestorian), namely, from the viewpoint of his contemporaries, Theodore bar Kōni, ${ }^{54}$ and Išo dad of Merv. ${ }^{55}$ Moshe Bar Kepha

${ }^{50}$ John of Damascus recorded a similar question raised by the Saracene (Muslim) to which John responsed from Christian Scripture and Islamic Scripture. See D. Sahas, John of Damascus on Islam, 151.

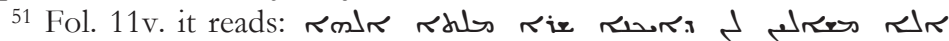

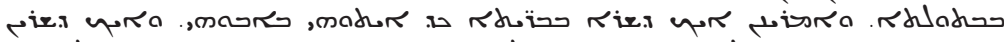

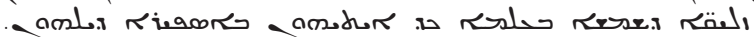

52 Unlike the earlier writers of the West Syriac tradition, Moshe Bar Kepha uses moderate and gentle words to describe Theodore of Mopsusestia. For example, Philoxenus of Mabbug describes Theodore in harsher terms. See John Watt, ed., Pbiloxenus of Mabbug Fragments of the Commentary on Matthew and Luke, CSCO 392, Scriptores Syri 171 (Louvain: Secrétariat du CorpusSCO, 1978), 25, 27, 49, 55-65; John Watt, trans., Philoxenus of Mabbug. Fragments of the Commentary on Matthew and Luke, CSCO 393, Scriptores Syri 172 (Louvain: Secrétariat du CorpusSCO, 1978) 22, 27, 49, 48-56.

${ }^{53}$ Fol. $11 \mathrm{r}$, on $1: 35$, it reads:

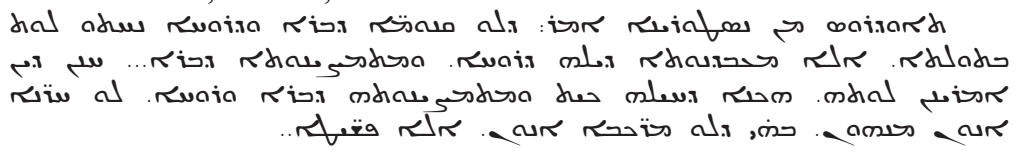

54 A. Scher, ed., Theodorus Bar Kōni, Liber Scholiorum, 67-68. Bar Kōni, in his Scholion writes that there are some who think that the Holy Spirit in this verse (Lk 1:35) is not the hypostasis of the Holy Spirit. By saying so, they departed from the truth.

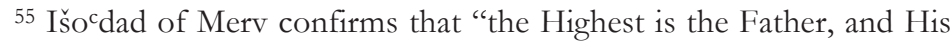
Power is the Word of God; it is evident that he calls the Son the Power." See M. D. Gibson, ed., The Commentaries of Isho dad of Merv Bishop of Hadatha 
elaborates, "but we say that the power and capability of the Son and the Holy Spirit are not separate from them. ${ }^{56}$ For the Son and the Holy Spirit are not combined but simple." However, Moshe Bar Kepha expresses his understanding of Theodore's caution about improper description of the transcendent God. Moshe Bar Kepha says that "we should not be unnecessarily anxious and cautious, and take deeds that befit God and attribute them to the humanity (of Jesus)."

As Moshe Bar Kepha criticizes Theodore of Mopsuestia, he also criticizes a revered theologian of his own tradition, namely, Philoxenus of Mabbug (d. 523). Moshe Bar Kepha argues that while Philoxenus confessed that God the Word immediately took flesh in the Virgin's womb, he erred when he said, "only after forty days the embryo received the rational soul." "58 According to the Greek teachers, Moshe Bar Kepha declares "together, both quickly and equally, the Word of God united with both the soul and the body in the Virgin's womb, and there is not to them an earlier or a later one. And we," Moshe Bar Kepha proceeds, "agree with the Greek teachers."

(c. 850 A.D.) in Syriac and English, Horae Semiticae No. VII; Vol. 3 (Cambridge: University Press, 1911), 152.

${ }^{56}$ Literally, it says: are not different from them.

${ }^{57}$ Fol. $11 \mathrm{r}$, it reads:

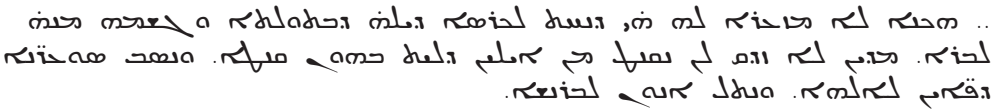

${ }^{58}$ Fol. 11v, it reads:

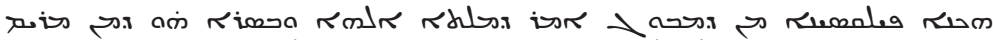

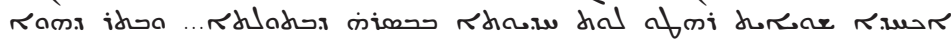
s

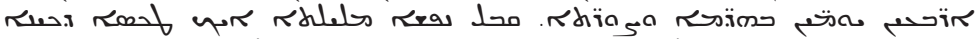

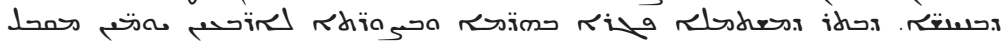

Cf. Watt, Philoxenus of Mabbug, (text) 36, 37; (tr.) 36, 32.

${ }^{59}$ Fol. $11 \mathrm{v}, 12 \mathrm{r}$, it reads:

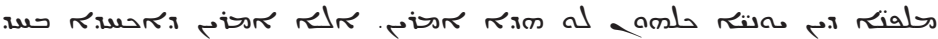

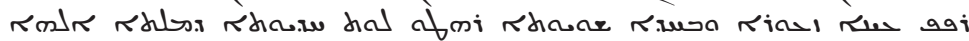

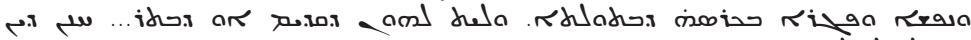

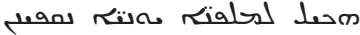




\section{Validating Christological Differences}

Harmonizing various Christological doctrines, Moshe Bar Kepha speaks about two births as he comments on "Behold, a Savior who is Lord Christ is born for you" (Lk 2:11). Moshe Bar Kepha confirms the divinity of the childbirth from Mary in the second birth, and he speaks about the first birth of the Son's hypostasis from the Father before there was time or space. $^{60}$

In this approach, Moshe Bar Kepha stresses the mainstream Christian theology of the eternal birth (the first birth) of the Son from the Father, and he also in non-dogmatic words expresses his confirmation about the divinity of the childbirth from Mary. With these words, Moshe Bar Kepha passes over the controversial dogma on whether Mary begot God-man or only the man to whom God the Word inseparably united or conjoined, because God the Word was born from eternity.

Moshe Bar Kepha elaborates on the second birth from the Virgin in which God showed his power, love, and marvelousness. His power was manifested, Moshe Bar Kepha explains, because although he is God, he was able to become man without change, ${ }^{61}$ and he revealed his love because he died for us; and he manifested his marvelousness because, being powerful, he saved us as the weak, and being alive in his nature, he saved us through his death. ${ }^{62}$

\footnotetext{
${ }^{60}$ Fol. 24r, on 2:11, it reads:

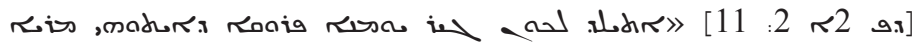

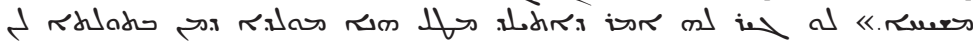

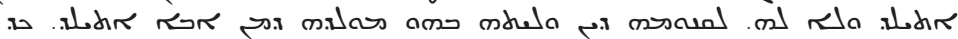

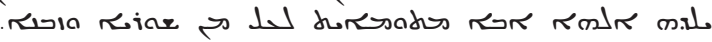

61 It became regular among Christian theologian to conclude their sentence with "without change" when they speak about the union of Christ's divinity with his humanity.

${ }^{62}$ Fol. 25r, on 2:11, it reads:

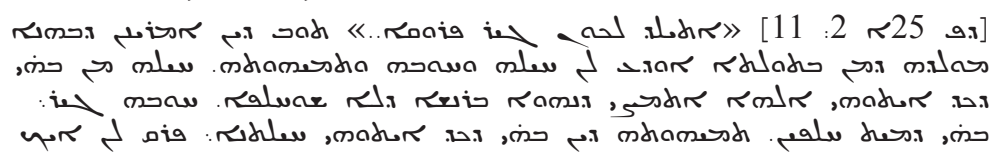


In this example, Moshe Bar Kepha also brings his Christology into harmony with all Syriac traditions. And again he avoids the watchwords and traditional, standard Christological formulae. In so doing, he intends to present an inclusive, "ecumenical" Christology.

Moshe Bar Kepha elaborates on a further controversial Christological topic, on Luke 1:35 to refute "the heretics" who say: "the Holy Spirit had created a temple or a residence, then the Son came and dwelled in it." ${ }^{33}$ Moshe Bar Kepha rejects the concept of Mary as a residence of God the Word as a "heretical" claim. On the same topic, 'Ammar al-Basri (d. 845), an East Syriac apologist, refutes the Muslims' misconception of the Christian doctrine "of the manifestation of God's economy in the body of a human," to mean that "we (Christians) say that he took up residence in the belly of Mary. ${ }^{, 64}$ Contrary to Muslims' claim, 'Ammar argues that the Christians speak about a manifestation of the Son as opposed to a "residence" of the incarnated God, which belongs to the essential being of God. ${ }^{65}$

To validate the Christological differences among Christians, Moshe Bar Kepha resorts to the Syriac theological theme of the incomprehensibility of the Godhead, as he comments on Christ being "a sign of contention" (Luke 2:34). He argues that the differences among Christians are due to the "incomprehensibility" of God the Word. "When Christians contend concerning him," Bar Kepha argues, "they all preach his incomprehensibility." Therefore, they all proclaim Christ as

\footnotetext{
mbos

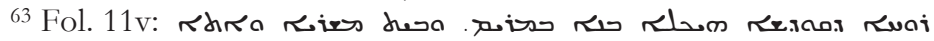

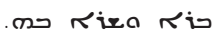

${ }^{64}$ M. Hayek, cAmmar al-Basri, apologie et controverses (Beyrouth: np., 1977) 36 .

${ }^{65}$ S. Griffith, “cAmmār al-Bașrị’s Kitāb al-Burhān: Christian Kalām in the First 'Abbāsid Century," Le Muséon 96:1-2 (1983):172-3.
} 
God the Word, at the same time refuting the counter claim (by Muslims) that Christ is merely a man. ${ }^{66}$

\section{The Last Days, the Eschaton}

Moshe Bar Kepha opportunely uses the eschatological passages in Luke chapters 17 and 18 to also reflect on the turbulent circumstances of his day. In so doing, he intends to comfort his people and raise their hopes on the one hand, and on the other hand to respond to the mockery of Christians by Muslims, who insist that their political dominion proves the truth of Islam. The Muslims often confronted Christians, saying: "if God has saved you, why do you endure such misery?" ${ }^{67}$ In Luke 17:22, which reads, "A time will come when you desire to see a day from the days of the son of man, but you will not see," Moshe Bar Kepha depicts the turbulent times the Christians have to endure, but he affirms that such turbulence is for a good purpose. He writes, "One may wonder if Christ wants to intimidate and terrify his followers? We say, on the contrary, Christ wants us to become courageous, ready and prepared for the time of affliction, for God's sake; Christ also wants us to become patient and steadfast." ${ }^{, 68}$

Reflecting on the loss of many Christians to Islam, Moshe Bar Kepha comments on Luke 18:8, which reads, "When the Son of Man comes, will he see faith on earth?" Moshe Bar Kepha explains that Christ has predicted that before his second coming many people would go astray. Moshe Bar Kepha

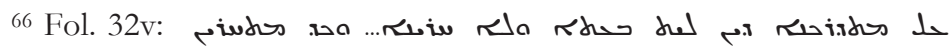
حلم,

67 Such a challenge is already recorded in the Qur'ān, Sura 5 (al-
}

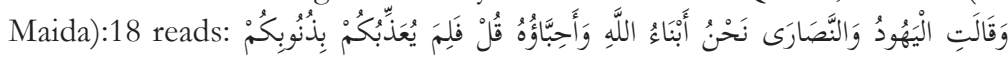
"But the Jews and the Christians say, 'We are the children of Allah and His beloved.' Say, 'Then why does He punish you for your sins?"”

${ }^{68}$ Fol. 89r:

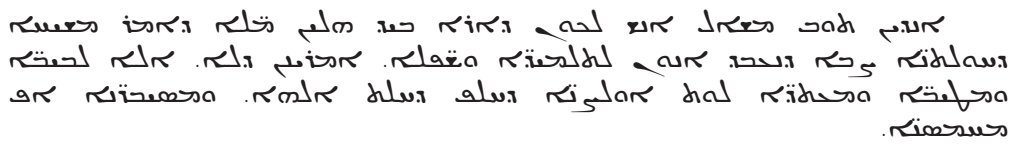


writes, 'Christ called 'faith' the belief one has in the existence of God. And saying 'will he?' he indicated the scarcity; and he said this: In my second coming few will be found who believe in God because their love will be dwindled for many reasons, and they will move from faith to no faith... also fewer will be found who trust the rewards which I have promised to the righteous ones." 69

\section{What defines Christian Faith?}

Commenting on the eschatological passages, especially Luke 18:8, which reads, "When the Son of man will come, will he find faith on earth?" Moshe Bar Kepha distinguishes between Christians and non-Christians. In order to group all Christians as a faithful people, he defines faith in two ways: First, believing in one true God, three hypostases (متمدم)), the Father, the Son and the Holy Spirit; second, trusting His words and promises. ${ }^{70}$ While "believing in one God" is a Christian doctrine since the Council of Nicaea (AD 425), in Moshe Bar Kepha's context, it serves as an apologetic theme in the face of Quranic dictum, "He is One God."

With such a definition, Moshe Bar Kepha presents the basic Christian faith that is accepted and defended by all Christian traditions. Additionally, with such basic and incontrovertible principles, the Christian communities could

${ }_{69}$ Fol. 90v:

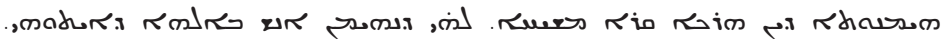

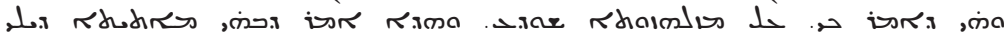

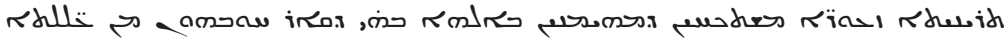

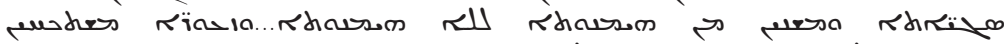

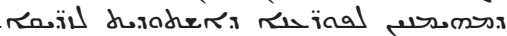

${ }^{70}$ Fol. 90v (on 18:8b):

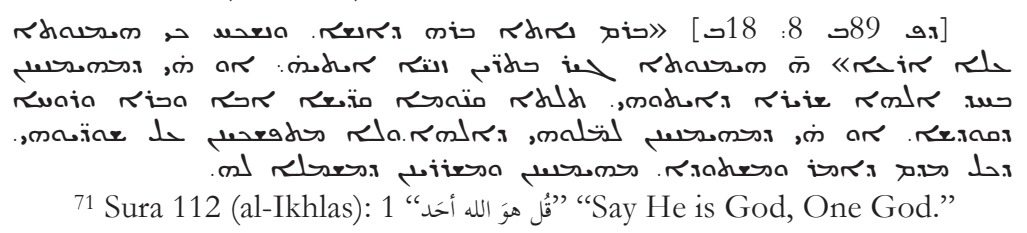


stand firm before the challenge of the Muslims, ${ }^{72}$ who would put the monotheistic Christian belief in question. ${ }^{73}$

\section{ConClusion}

Through this sample of citations, it becomes clear that Moshe Bar Kepha's central theme is the divinity of Jesus, in the context of the Islamic challenge, in his Commentary on Luke. Moshe Bar Kepha fulfills his attempt to instruct all Syriac Christian communities with an inclusive, comprehensible, accessible theology. Moshe Bar Kepha's theology sets a precedent for mutual understanding of theology and Christology among various Christian traditions. At the same time, he communicates his teachings to the Christian communities in response to the Muslims despite the forbidding conditions as he writes surreptitiously and prudently. In so doing, he achieves his purpose of defending Christianity from aggressive Muslim derision and doctrinal polemics. At the same time, he seeks to edify and unite the Christian community. Thus, indeed, Moshe Bar Kepha is at once an exegete and an apologist proper.

\section{BIBLIOGRAPHY}

Abouna, Albert. The History of the Eastern Syriac Church [تاريخ الكنيسة السريانية الشرقية, Vol. 2. Beirut: Dar al-Mashriq, 1993.

$72 \mathrm{~S}$. Griffith observes the usage of the monthestic along with the trinitarian Christian formula by Nonnus of Nisibis as a hot topic of Christain-Muslims controversies. See S. Griffith, "The Apologetic Treatise of Nonnus of Nisibis," ARAM 3:1-2 (1991 [1993]): 122.

73 All Christian apologists refuted the Muslims' claim that professing trinity implies tritheism. In the instance of 'Ammar al-Basri, see S. Griffith, "cAmmār al-Bașrī's Kitāb al-Burhān: Christian Kalām in the First 'Abbāsid Century," Le Muséon 96:1-2 (1983): 170; and in the instance of Abu Ra itha, see S. Griffith, "Habib ibn Hidmah Abu Ra'itah, a Christian mutakallim of the First Abbasid Century," Oriens Christianus 64 (1980): 175, 181-2. 
'Abd al-Jabbar. The Critique of Christians: A Parallel EnglishArabic Text, S. Samir, ed., G. Reynolds, trans. Provo: Brigham Young University Press, 2010.

Barsoum, Ignatius Aphram and Chabot, J.B. eds. Chronicon anonymum ad annum Christi 819 pertinens. CSCO 81, Syr. 36. Paris: Secrétariat du CorpusSCO, 1920.

Brock, S., and Kiraz, G. Ephrem the Syrian: Select Poems. Provo: Brigham Young University Press, 2006.

Bedjan, Paulus, ed. Liber columbae seu Directorium monachorum Gregorii Barhebraei. Paris / Leipzig: Otto Harrassowitz, 1898.

Bundy, David. "Criteria for Being "in communione" in the Early Syriac Church.” Augustinianum 25:3 (1985): 597-608.

Chabot, J. B. ed. Chronique de Michel le Syrien, Vol. 4. Paris: Culture et Civilisation, 1963.

Cook, Michael Allan. "The Origins of Kalam." Bulletin of the School of Oriental and African Studies 43:1 (1980): 32-43.

Fiey, Jean-Maurice. Chrétiens syriaques sous les Abbassides surtout à Bagdad (749-1258). CSCO 420, Subs. 59. Louvain: Secrétariat du CorpusSCO, 1980. . Abwal Al-Nasara [هوال النصارى في خافة بني عباس]. Translated by Husni Zinah. Beirut: Oriental Library, 1990.

Gibson, M. D. ed. The Commentaries of Isho' dad of Merv Bishop of Hadatha (c. 850 A.D.) in Syriac and English. Horae Semiticae No. VII; Vol. 3. Cambridge: University Press, 1911.

Gismondi, Henricus. ed., Maris Amri et Slibae, De Patriachis Nestorianorum Commentaria. Rome: Excudebat de Luigi, 1896.

Graf, Georg, ed. Die Scbriften des Jacobiten Habîb ibn Hidma Abû Râita. CSCO 130, Arab. 14. Louvain: L. Durbecq, 1951. 
Griffith, S. "Disputes with Muslims in Syriac Christian Texts: From Patriarch John (d. 648) to Bar Hebraeus (d. 1286)." Pages 251-273 in Religionsgespräche im Mittelalter. Edited by Lewis, B. and Niewöhner, F. Wolfenbütteler MittelalterStudien 4. Wiesbaden: Otto Harrassowitz, 1992.

- "Free Will in Christian Kalam: Moshe Bar Kepha Against the Teachings of the Muslims." Le Muséon 100:1-2 (1987): 143-159.

. “c Ammār al-Baș rî̀s Kitāb al-Burhān: Christian Kalām in the First 'Abbāsid Century." Le Muséon 96:1-2 (1983): 145-181.

- "The Apologetic Treatise of Nonnus of Nisibis," ARAM 3:1-2 (1991 [1993]): 115-138.

. "Ammār al-Baș rī’s Kitāb al-Burhān: Christian Kalām in the First 'Abbāsid Century." Le Muséon 96:1-2 (1983): 145-181.

"Habib ibn Hidmah Abu Ra'itah, a Christian mutakallim of the First Abbasid Century." Oriens Christianus 64 (1980): 161-201.

. "Chapter Ten of the Scholion: Theodore Bar Kônî's Apology for Christianity," Orientalia Christiana Periodica 47 (1981): 158-188.

. "Disputing with Islam in Syriac: The Case of the Monk of Bêt Halê and a Muslim Emir," Hugoye: Journal of Syriac Studies 3:1 (2000): 1-23.

Harun, A. ed. Rasail al-Jahiz [رسائل الجاحظ] Vol. 3. Cairo: al-Hangi, 1979.

Hayek, M. 'Ammar al-Basri, apologie et controverses. Beyrouth: np., 1977.

Holmberg, Bo, "A Reconsideration of the Kitāb alMagdal." Parole de l'Orient 18 (1993): 255-273. 
. "The Trinitarian Terminology of Israel of Kashkar (d. 872)." ARAM 3 (1991 [1993]): 53-82.

Leloir, Louis, ed. and trans. Saint Éphrem. Commentaire de l'Évangile Concordant: texte syriaque (Manuscrit Chester Beatty 709). Chester Beatty Monographs 8. Dublin: Hodges Figgis, 1963.

McCarthy, Carmel, Saint Ephrem's Commentary on Tatian's Diatessaron: An English Translation of Chester Beatty Syriac Ms 709 with Introduction and Notes, Journal of Semitic Studies Supplements 2. Oxford: Oxford University Press, 1993.

Mingana, A. trans. The Book of Religion and Empire. Manchester: Longmans-Green, 1922.

Moffett, Samuel. A History of Christianity in Asia, Vol. 1. New York: HarperSanFrancisco, 1992.

Nuweihed, A. ed. Kitab al-din wal-dawla [كتاب الدين والدولة]. Beirut: Dar al-Afaq al-Jadida, 1979.

Penn, Michael Philip. "John and the Emir: A New Introduction, Edition and Translation.” Le Muséon 121:12 (2008): 65-91.

Riza, Nizanr, ed. Iwan al-Anbaa fi Tabaqat al-Atibaa [عيون الأنباء في طبقات الأطباء. Beirut: Dar Maktabat al-Hayat, 1965.

Thomson, Robert W. Nonnus of Nisibis, Commentary on the Gospel of Saint John. Atlanta: Society of Biblical Literature, 2014.

Saadi, Abdul-Massih. "The Letter of John of Sedreh: A New Perspective on Nascent Islam." Journal of the Assyrian Academic Society 11.1 (1997): 68-84.

" "Moshe Bar Kepha's Commentary on Luke: A Ninth Century Apology.” Ph.D. dissertation, Lutheran School of Theology at Chicago, 1999.

Sahas, Daniel J. John of Damascus on Islam: The "Heresy of the Ishmaelites”. Leiden, The Netherlands: Brill, 1972. 
Scher, Addai, ed. Theodorus Bar Kōni Liber Scholiorum. CSCO Syr. II. 66. Paris: Typographeo Reipublicae, 1912.

ibid. Theodorus Bar Kōni, Liber Scholiorum. CSCO 69, Scriptores Syri 26. Louvain: Secrétariat du CorpusSCO, 1960.

Taylor, David. "The Syriac Tradition." Pages 201-224 in The First Christian Theologians: An Introduction to Theology in the Early Church. Edited by G. R. Evans, 201-224. Malden/ Oxford/ Victoria: Blackwell, 2004.

Van Roey, Albert, ed. Nonnus de Nisibe. Traité apologétique. Bibliothèque du Muséon 21. Louvain: Bureaux du Muséon, 1948.

Tritton, A. S. The Caliphs and their Non-Muslim Subjects, a Critical Study of the Covenant of Umar. London: Oxford University Press, 1930.

Troupeau, Gérard. "Le livre de l'unanimité de la foi de 'Alī ibnDāwud al-Arfādī," Melto 5:2 (1969): 197-219.

Watt, John W. ed. and trans. Philoxenus of Mabbug. Fragments of the Commentary on Matthew and Luke. CSCO 392-393, Syr. 171-172. Louvain: Secrétariat du CorpusSCO, 1978.

Wensinck, Arent Jan. Bar Hebraeus's Book of the Dove, together with Some Chapters from his Ethikon. De Goeje Fund 4. Leiden: E.J. Brill, 1919. 